\title{
OBITUARIES
}

\section{Jean ('Dokkie') Nel (20/04/1941 - 08/09/2011)}

'Dokkie' is op 20 April 1941 in Utrecht, Natal, gebore. Hy en sy suster, Johanna, was 'n tweeling in 'n gesin van sewe kinders. Hy ontvang sy skoolopleiding aan die Laerskool Hendrina, en matrikuleer in 1958 aan die Hoërskool Ermelo. In 1959 doen hy sy nasionale diensplig by die Lugmag Gimnasium in Pretoria. In 1960 skryf hy in vir 'n BA-graad aan die Universiteit van Pretoria en kwalifiseer as onderwyser. Hy besef egter gou dat hy nie vir die onderwysberoep uitgeknip is nie. Daarna is hy vir 'n tydperk 'n vryskut-joernalis, voordat hy 'n beurs bekom en inskryf vir die graad MB ChB aan die Universiteit van Pretoria.

Hy voltooi sy studie as mediese dokter, en trou daarna met die liefde van sy lewe, Elmien. Hy doen sy hospitaaljaar by die Universitas Hospitaal in Bloemfontein, waarna hy direk begin met spesialisasie as ginekoloog/verloskundige. Hy behaal die graad MMed (O et $\mathrm{G}$ ) in 1976, en verhuis kort daarna na Nelspruit, waar hy 'n privaat praktyk begin en vir die merendeel van 33 jaar praktiseer.

Hy was baie geliefd by vriende, kollegas en pasiënte. Hy was veral bekend as 'n buitengewoon vaardige vaginale chirurg. Sy liefde vir gholf, vir die see, en vir hoë-spoed ski-bote was wel bekend. Ek dink met groot deernis terug aan Tugela-riviermond, die Beach Buggy, die kreef, en veel meer. Hy was 'n passievolle gesinsman.

Dokkie sterf op 8 September 2011 in Nelspruit. Die standaard van sy professionele praktykvoering word nou deur sy seun Jean (Klein Jean) in die Laeveld voortgesit.

Elmien - aan jou en die drie kinders - sterkte en voorspoed. Ek dra ook die innige meegevoel oor van die oorblywende lede van die oorspronklike 'Groot vyf', waarvan Dokkie 'n baie gewaardeerde en geliefde lid was.

\section{Emile Welgemoed}

The anaesthetist profoundly impacts on surgical intervention outcomes. Dr Emile Welgemoed will be considered by those who worked with him to have been an anaesthetist exemplar. Emile died tragically during a farming accident in Uniondale on 21 January 2012 at the age of 41 .

Emile was in private practice in Knysna for much of his short career and exemplified the traits of an excellent anaesthetist. This included good communication skills which facilitated optimal pre-operative planning and a seamless execution of his lists. His confidence and relaxed attitude created a pleasant theatre environment. Emile was also expeditious, another great attribute in an anaesthetist, especially when lists are long and there are many patients. He treated all staff, irrespective of their rank or job description, with respect.

Although he worked in a small coastal private hospital, Emile kept abreast of developments in his field and ensured that his skills and knowledge were up to date. More recently he developed an interest in chronic pain, demonstrating his compassion for a group of patients who are extremely difficult to manage.

Emile was a great friend and many of his work relationships extended into a social context, once again demonstrating his extremely amicable nature. He was a committed father and husband and demonstrated that rare art of being able to balance work and life. We would do well to remember his life as we progress through our careers.

He leaves behind his wife, Heidi, and children, Sebastian and Lili.

Stephen Jeffery

Wilhelm Cronje 